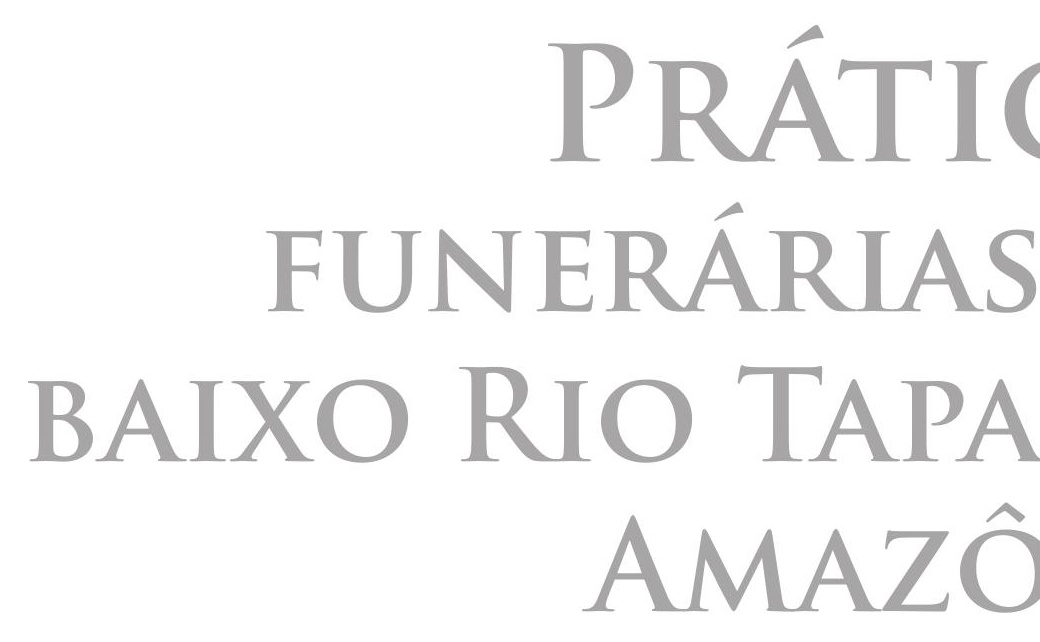




\section{PRÁTICAS FUNERÁRIAS NO BAIXO RIO TAPAJÓS, AMAZÔNIA}

\section{DIEGO BARROS FONSECA}




\title{
PRÁTICAS FUNERÁRIAS NO BAIXO RIO TAPAJÓS, AMAZÔNIA
}

\section{Resumo}

$\mathrm{O}$ artigo trata de uma série de urnas e vasilhas relacionadas a práticas de sepultamento provavelmente de indígenas Mundurucu, no baixo rio Tapajós, vindos do sítio arqueológico Nossa Senhora do Perpétuo Socorro (N.S.P. Socorro) - Itaituba, Pará. Avalia-se então as semelhanças com dados etnohistóricos e arqueológicos sobre as práticas funerárias na região, a descrição das escavações em laboratório, apresentando dados e interpretações sobre os vestígios osteológicos encontrados, contribuindo com os debates sobre as práticas funerárias na região Amazônica.

Palavras-Chave: Práticas Mortuárias, rio Tapajós, Amazônia.

\section{FUNERARY PRACTICES IN THE LOWER TAPAJÓS RIVER, AMAZON}

\begin{abstract}
The paper deals with a series of urns and vessels related to burial practices probably of indigenous Mundurucu, in the lower Tapajós River, from the archaeological site of Nossa Senhora do Perpétuo Socorro (N.S.P. Socorro) - Itaituba, Pará. The paper then evaluates the similarities with ethnohistorical and archaeological data on funerary practices in the region, the description of the excavations in laboratory, presenting data and interpretations on the osteological traces found, contributing to the debates about funerary practices in the Amazon region.
\end{abstract}

Keywords: Funerary practices, Tapajós River, Amazon. 


\section{PRÁCTICAS FUNERÁRIAS EN EL BAJO RÍO TAPAJÓS, AMAZONIA}

\section{Resumen}

El artículo se trata de una serie de urnas y vasijas relacionadas a prácticas de sepultura, probablemente de los indígenas Mundurucu, en el bajo río Tapajós, extraídas del sitio arqueológico Nuestra Señora del Perpetuo Socorro (N.S.P. Socorro) -Itaituba, Pará. Se examinan las semejanzas con datos etnohistóricos y arqueológicos sobre las prácticas funerarias de la región, la descripción de las excavaciones en laboratorio y se presentan datos e interpretaciones sobre los vestigios osteológicos encontrados, contribuyendo con los debates sobre las prácticas funerarias en la región Amazónica.

Palabras clave: Prácticas mortuorias, río Tapajós, Amazonia 


\section{INTRODUÇÃO}

Práticas funerárias pretéritas na Amazônia são mencionadas constantemente nas descrições e nos estudos arqueológicos da região, porém é recente a utilização deste tipo dados para entender processos que envolvam a morte e os símbolos ritualizados nas comunidades indígenas. É muito claro que, até a segunda metade do século XIX, os estudos de práticas funerárias estão separados dos estudos de sítios arqueológicos, como contextos desassociados dentro do mesmo espaço, entendendo os sepultamentos, apenas como restos ósseos humanos, esquecendo os gestos funerários e/ou os símbolos que o representam, assim como o momento ritual relacionado ao ato da morte, este último, gerenciado pelos vivos.

A partir do início do século XX, cresce a quantidade de estudos relacionados a restos humanos bem conservados e práticas mortuárias, mesmo assim, era evidente a carência de profissionais especializados. Além disso, os estudos direcionavam-se à compreensão morfológica e estudos sobre paleopatologia de materiais ósseos, privando as análises alinhadas ao entendimento do contexto cultural, com interesse disciplinar restrito muito evidente até duas décadas, sobretudo na Arqueologia Amazônica.

Recentemente, ficou óbvio que práticas funerárias não se separam do contexto cultural do sítio a ser estudado, são partes do mesmo e assim devem ser interpretadas. Em alguns casos, a evidência de práticas mortuárias junto a dados osteológicos e interpretativos sobre a cultura material definem interpretações outras, mais coerentes e lógicas sobre qualquer sítio arqueológico, como o modo como os mortos eram tratados, a confirmação ou não $\mathrm{da}$ existência de uma hierarquia no sítio, a importância do cadáver para a comunidade, os gestos rituais e simbólicos que são significativos, demonstrando a complexidade da realidade dessas populações nos espaços de vivência cotidiana.

\section{2 - PRÁTICAS MORTUÁRIAS NO BAIXO CURSO DO RIO TAPAJÓS}

As regiões de Santarém e Itaituba eram dominadas por índios Mundurucu e Tapajós. Os Mundurucu ocupavam as margens do rio Tapajós desde o século XVIII, "tanto no seu curso baixo e médio, como a região que se estende desde ambas as margens desse rio para o interior do território, estava densamente povoado pelos Mundurukú" (Menendez 1981-82: 337), sendo a região de Itaituba espaço de influência Mundurucu. Os Tapajós ocupavam a foz do rio, em sua margem direita (Santarém) e o planalto de Belterra (Stenborg et al. 2012).

Os Tapajós são descritos para esta região desde a época do contato, exercendo inclusive influência sobre outras comunidades indígenas nessa região (Acuña 1994[1641]; Bettendorf 1909[1698]; Barbosa Rodrigues 1875; Nimuendajú 1949; Heriarte 1962; Florence 2009).

Cristóbal de Acuña (1994 [1641]), padre jesuíta espanhol que foi o cronista da primeira expedição a navegar no 
rio Amazonas desde suas nascentes até sua foz, descreveu os índios "Tapajoses" como guerreiros temidos inclusive pelos portugueses, pois eram muitos hábeis no uso de flechas envenenadas e mortais. Segundo tal relato, as margens do rio eram povoadas por "bárbaros", que tinham boas terras e boa quantidade de alimentos, os mesmos também teriam ídolos pintados.

Mais tarde, Bettendorf (1909[1698]), religioso jesuíta que chegou ao norte do país em 1661, mandado para fundar missão jesuítica na aldeia dos Tapajós, atual cidade de Santarém, situada à foz do grande rio, destacou que os índios Tapajós tinham casas escondidas na mata, locais onde cultuavam seus mortos e guardavam os restos mumificados dos que possuíram então maior prestígio social na comunidade, eram reverenciados em celebrações ritualísticas e posteriormente destacados como oráculos. Os atos funerários não agradaram aos portugueses, que decidiram reprimir de forma violenta estas práticas, destruindo as "múmias" e tendo como justificativa a ideia de que as cerimônias eram "demoníacas". Vale destacar que o discurso sobre ação demoníaca é constante nos relatos dos missionários.

Barbosa Rodrigues (1875) destaca um domínio Tapajônico até a cachoeira Boruré, próximo de Itaituba, descreveu que com o correr dos anos foram os índios Tapajós estendendo-se pela margem direita até a cachoeira, tomando várias denominações, porém conservando os mesmos costumes.

Sobre as práticas de sepultamento dos Tapajós, Barbosa Rodrigues (1875) afirmou que usavam 'igaçauas' duplas para guardarem os ossos, colocavam os ossos dentro de uma espécie de "panela", que era depositada dentro de um pote ornado com desenhos de linhas e formas geométricas feitas com tinta vermelha. As 'igaçauas' eram enterradas juntas com a boca voltada para cima. Em um sítio próximo ao rio Piracanã, o mesmo escavado por Hartt (1885), encontrou inúmeros vestígios de 'igaçauas' e fragmentos de louça (uma sendo grosseira e sem desenhos, outra mais fina e com desenhos em formas geométricas e com tinta "encarnada”). De maneira geral, afirmou que os índios Tapajós ou suas sub-divisões viviam no baixo Tapajós, até a época em que os portugueses começaram a sua conquista, obrigando-os a fugirem para o interior da floresta (Barbosa Rodrigues 1875: 126).

Nimuendajú (1949) - etnólogo de origem alemã que dedicou parte de sua vida a pesquisar comunidades indígenas desde 1905 até a sua morte em 1945 - inferiu que o domínio Tapajônico chegava até $50 \mathrm{~km}$ ao sul de Santarém, na localidade de Aramanahí, baseando-se principalmente pela dispersão cerâmica. Considerou ainda que os Tapajós não enterravam os seus mortos, pois observou a ausência de sepultamentos nessas ocupações tapajônicas, apesar da existência de ocorrência de urnas em algumas comunidades indígenas, como no caso de um tipo cerâmico relacionado à cultura Sapupé em Itaituba, na margem esquerda do rio Tapajós (Nimuendajú (1981[1947]; 1949; 2004; Martins 2010; Martins 2012a; Martins 2012b; Martins 2012c). 
O cronista Heriarte (1962) relatou sobre a ocupação dos Tapajós por volta de 1637, revelando que os índios consumiam ossos triturados e queimavam os objetos pertencentes ao morto, desta forma: "quando morre algum d'estes índios, (...) os poem em umas cazas que tem feitas so para elles, aonde estam a mirrar e a consumir a came: e os ossos moidos os botam em vinho, e seus parentes e mais povos o bebem" (Heriarte 1962: 36-37). Em outra observação sobre a morte de algum índio Tapajó, descreve que os índios colocam o cadáver deitado em uma rede, posicionando aos pés do morto todos os bens que possuía em vida.

De forma muito breve, Hércules Florence (2007) chegou a comentar sobre um aldeamento a leste de Santarém que era chamada de Tapajós.

Ao tratar de descrições sobre a margem esquerda do rio Tapajós, temos referências sobre o domínio dos índios Mundurucu desde o alto Tapajós até a região de Itaituba (Bates 1979; Barbosa Rodrigues 1875; Hartt 1885; Nimuendajú 1981 [1947]; Horton 1948; Hilbert 1958; Coudreau 1977; Florence 2007).

É assim, que em 1852, Henry Bates (1979:182), um naturalista inglês que viajou para o Brasil em 1848 e ficou até 1859 , verificou a presença de índios Mundurucu próximo à Itaituba e no rio chamado de Cupari, que fica a nordeste desta cidade, destacando que os indígenas tinham um costume "diabólico" de cortar as cabeças de seus inimigos mortos e preservá-las como troféus em suas casas.
Barbosa Rodrigues (1875) por sua vez, afirmou que os Mundurucu dominavam o alto Tapajós, onde eram conhecidos como caras pretas, observando que eles faziam um interessante rito funerário para os seus guerreiros mortos em batalha. Resumidamente, faziam o descarne do corpo, pegavam ossos guardados no que é chamado de "quartel", e realizavam um novo festejo, que poderia demorar cerca de um mês, sempre na presença dos ossos do falecido. Após todos os ritos, colocavam os ossos dentro de uma 'igaçaua' e os esterravam para sempre. Quando as mortes aconteciam na aldeia, os indivíduos "são vestidos com as suas roupagens guerreiras e enterrados dentro de casa" (Barbosa Rodrigues 1875: 150).

Hartt (1885) era um geólogo canadense-americano que, por volta de 1871, encontra diversas urnas funerárias em uma localidade chamada de Cafezal, na margem esquerda do rio Tapajós, a cinco ou seis milhas de Itaituba, relatando que em "tempos relativamente modernos existia ali uma maloca dos Índios Mundurucus" (Hartt 1885: 15). Estas urnas estavam quebradas devido ao nivelamento do terreno feito pelo proprietário do local.

$\mathrm{Na}$ mesma ocasião Hartt escavou 15 urnas, que continham ossos humanos e dentes, sendo algumas delas largas e rasas como panelas, a maior delas medindo 1,06 $\mathrm{m}$ de diâmetro e $0,30 \mathrm{~m}$ de altura. Existem semelhanças no tamanho e na presença de materiais no interior das urnas com as encontradas no sítio Nossa Senhora do Perpétuo Socorro (sítio estudado neste artigo). Hartt informa que encontrou no inte- 
rior de uma das urnas, uma grossa chapa redonda de cerâmica sem ornamentação, posicionada horizontalmente e concluiu ser parte de um forno cerâmico. Sobre essa chapa haviam diversos ossos de membros superiores e inferiores de um indivíduo, estando alinhados paralelamente sem aparente incineração, além de um osso do crânio. Já em outras urnas foram encontrados fragmentos de ossos misturados à terra preta, considerando a possibilidade de incineração dos ossos (Hartt 1885, p. 15).

Em outra urna descreve a existência de fragmentos de ossos "podres e quebrados”, também misturados à terra preta, diante do avançado estado de decomposição dos ossos e pelo grau de mistura com a terra preta, não conseguiu precisar se os ossos foram incinerados, contudo, após observação mais detalhada, infere que os ossos foram sim incinerados, constatando a prática de cremação.

Sobre uma urna menor, Hartt (1885) encontrou apenas parte de um esqueleto, considerando ser "incompreensível" que fizessem um ritual de sepultamento somente para parte do corpo. Uma explicação possível é o costume Mundurucu de enterrar apenas partes do corpo quando da morte de um indivíduo fora da aldeia. Segundo Hartt (1885), os Mundurucu já eram conhecidos por volta de 1770 , época em que desceram o rio Tapajós, fundando sua primeira aldeia em Santa Cruz, na margem esquerda do Tapajós, abaixo de Itaituba. $\mathrm{Na}$ época, o baixo Tapajós era povoado pelos brancos que faziam negociações no rio.
A partir do momento que os Mundurucu se tornaram tutelados pelo governo e pela igreja, cessaram o uso de machados de pedra e pararam de enterrar os mortos em potes. Tal mudança de comportamento deixa Hartt em dúvida quanto ao fato da "estação funerária" pertencer aos índios Mundurucu, a não ser que eles tivessem ocupado a área antes dos portugueses.

O mapa de Nimuendajú (1981[1947]) coloca os Mundurucu como ocupantes da região de Itaituba e possivelmente do sítio N. S. P. Socorro desde 1862 até 1894.

Donald Horton (1948: 271), que era etnógrafo, em sua descrição sobre os Mundurucu, no final do século XVIII e início do XIX, comenta que eram um povo guerreiro, que expandiam seus territórios ao longo do rio Tapajós e áreas adjacentes, chegando ao seu limite no início do século XIX, quando foram derrotados pelos "neo-brasileiros" e acabaram localizando seus assentamentos ao "longo do meio do Rio Tapajós". No que se refere às práticas mortuárias, Horton (1948: 279) revela que os parentes maternos do falecido lhe cortam o cabelo, pintam seu rosto e realizam um prolongado período de lamentação por sua morte. O cadáver é envolto em uma rede e colocado em posição sentada, com seus joelhos flexionados em uma cova cilíndrica sob o piso da habitação; junto a ele são colocados alguns de seus bens como acompanhamento. Os indivíduos de alta posição social são exumados e queimados após a carne ter decaído; as cinzas são enterradas posteriormente em urnas. Quando um guerreiro é morto em 
campo de batalha distante da aldeia, sua cabeça é trazida de volta e colocada em exibição junto a seus ornamentos, trombetas e armas.

$\mathrm{Na}$ sequência do momento de exibição, acontece uma festa em honra ao falecido, a cabeça do morto é pendurada num colar no pescoço de sua mãe, viúva ou irmã, e seus companheiros guerreiros comprometem-se em vingar sua morte. Segue-se um longo período de luto até o momento em que a cabeça do falecido é enterrada em sua casa. Hilbert (1958), etnólogo e arqueólogo alemão que realizou pesquisas na Amazônia brasileira através do Museu Paraense Emílio Goeldi, descreveu urnas escavadas por Frei Protásio Frikel, em julho de 1957, na missão franciscana "São Francisco do Cururú", fundada no ano de 1911 e que encontrava-se à margem esquerda do alto rio Tapajós, cerca de $120 \mathrm{~km}$ acima do rio Cururú. A área pertenceria aos índios Mundurucu, estendendo-se do norte até a margem do Amazonas. Segundo Hilbert, a distribuição das "vasilhas" não apresentava um padrão, basicamente eram urnas de sepultamento secundário contendo ossos longos ou esfarelados, sem oferendas dentro ou fora da urna. O que encontrou foram alguns fragmentos de cerâmica do tipo cuscuzeiro e sugeriu que o local poderia ser tanto um sítio cemitério quanto de habitação.

Henry Coudreau (1977), explorador francês, relata suas observações entre os anos de 1895 e 1896, também sobre os Mundurucu, observando que a prá- tica de sepultamento consistia em enrolar o cadáver em uma rede e enterrá-lo de cócoras em uma cova que tinha uma forma de poço, bem semelhante ao que Horton (1948) já tinha descrito. Hércules Florence (2007), que era um inventor, desenhista, polígrafo e pioneiro da fotografia franco-brasileiro juntou-se à expedição do Barão Georg Heinrich von Langsdorff como desenhista, e fez seus relatos entre os anos de 1825 a 1829, onde destacou que na margem esquerda do rio Tapajós, existiam várias concentrações de índios Mundurucu, em especial na margem oposta à cidade de Itaituba, onde está o distrito de Uxituba, local habitado por alguns portugueses e índios Mundurucu.

A partir dos relatos, ora descrevendo os atos funerários, ora afirmando a presença de urnas funerárias, fica claro que a região de Itaituba e seus arredores assemelham-se, sobretudo, aos padrões de sepultamento, mudando basicamente alguns modos de tratamento direto sobre o corpo (como esquartejamento e/ou descarne), mudanças que podem ter sido influenciados pelo contato entre as comunidades dessa região antes mesmo da colonização ou pela mudança na dinâmica cultural e ritual fruto do contato com os colonizadores. Os dados levantados para a região apresentam um padrão de sepultamento geralmente secundário após o tratamento direto sobre o corpo.

Um ponto importante nesses contextos, refere-se a ideia de contato e mudança cultural relacionados ao trata- 
mento sobre o corpo do falecido como algo muito adaptável, alinhado às dinâmicas de transformação do espaço e de ações sociopolíticas, diferentemente de ações rituais e acima de tudo, os sepultamento constantemente secundários.

Desta maneira, a ação sobre o corpo pode ser variada, porém o ritual em si é algo linear e relevante nessas comunidades, já que reveste de importância as diversas fases do luto até o sepultamento do indivíduo (Schaan 2003, 2010; Martins 2010, 2012a, 2012b, 2012c; Rocha 2012; Py-Daniel 2015).

\section{3 - ESCAVAÇÕES DE URNAS DO SÍTIO NOSSA SENHORA DO PER- PÉTUO SOCORRO - ITAITUBA: DO CAMPO AO LABORATÓRIO}

As escavações no sítio Nossa Senhora do Perpétuo Socorro ocorreram no âmbito do processo de licenciamento para a pavimentação da rodovia BR163 (Trecho Guarantã do Norte/ MT ao entroncamento com a BR-230) e da rodovia BR-230 (Trecho Miritituba a Rurópolis/PA). O sítio está localizado no município de Itaituba, no estado do Pará, na margem esquerda do rio Tapajós, em uma propriedade na saída do canal Piracanã.

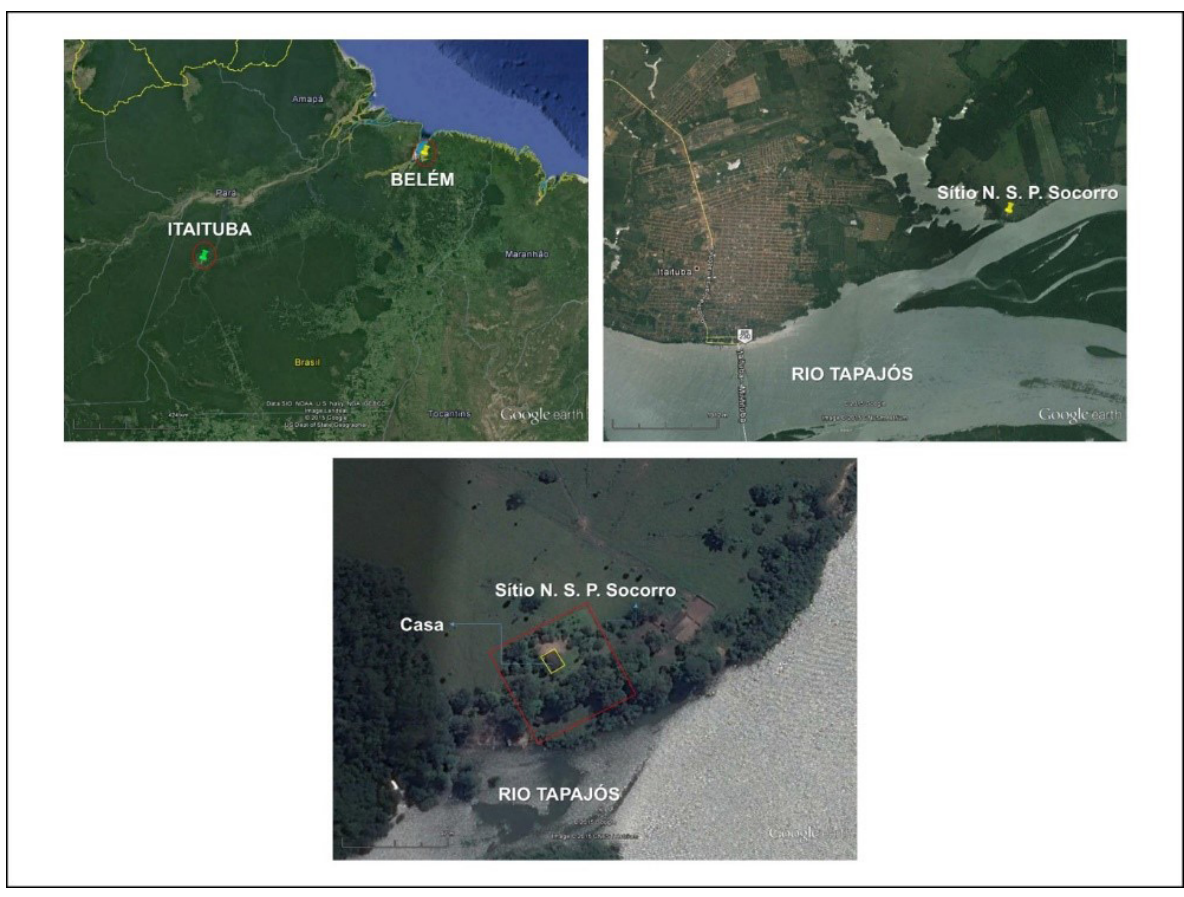

Figura 1 - Mapa de Localização do sítio N.S.P. Socorro em imagem de satélite. Fonte: Google Maps. 
As escavações ocorreram em três etapas. As duas primeiras consistiram no salvamento arqueológico de urnas que estavam aflorando em superfície e a terceira etapa compreendeu mapeamento topográfico, prospecção geofísica e salvamento de outras urnas que não foram resgatadas nos momentos anteriores. A primeira etapa foi desenvolvida entre os dias 20 a 29 de julho de 2009, a segunda entre 19 a 29 de outubro de 2009 e a terceira entre 15 a 25 de maio de 2010.

A parte mais elevada do sítio é constituída por um terreno semiplano, onde existe uma residência. $\mathrm{Na}$ frente dessa casa visualiza-se o rio Tapajós e à medida que se caminha em direção ao rio, o local apresenta um declive. Existem diversas construções sobre o terreno, assim como muitas árvores frutíferas e uma grande área de pasto, com gado bovino e criação de animais domésticos que estão localizadas na parte de trás da casa.
O material oriundo desse sítio foi coletado basicamente em duas áreas de escavação, nomeada por Área de Escavação 1 , que se localiza nos fundos da residência e a Área de escavação 2 que localiza-se na frente da casa, na área mais próxima do rio, em uma parte semiplana, cercada por muitas mangueiras entre outras árvores.

A área de escavação 1 é praticamente plana e desprovida de vegetação, muito por ser varrida e frequentemente pisoteada por pessoas e/ou animais, ou mesmo pelas chuvas que "lavam" o terreno, ações que contribuíram para o afloramento das vasilhas. Nesta área foi aberta uma escavação $2 \times 1 \mathrm{~m}$ na primeira etapa de campo, na segunda etapa a escavação foi ampliada em três direções, identificadas como: extensão trincheira, extensão A e extensão B. Por fim, foi escavada na terceira etapa de campo outra unidade chamada de 6.

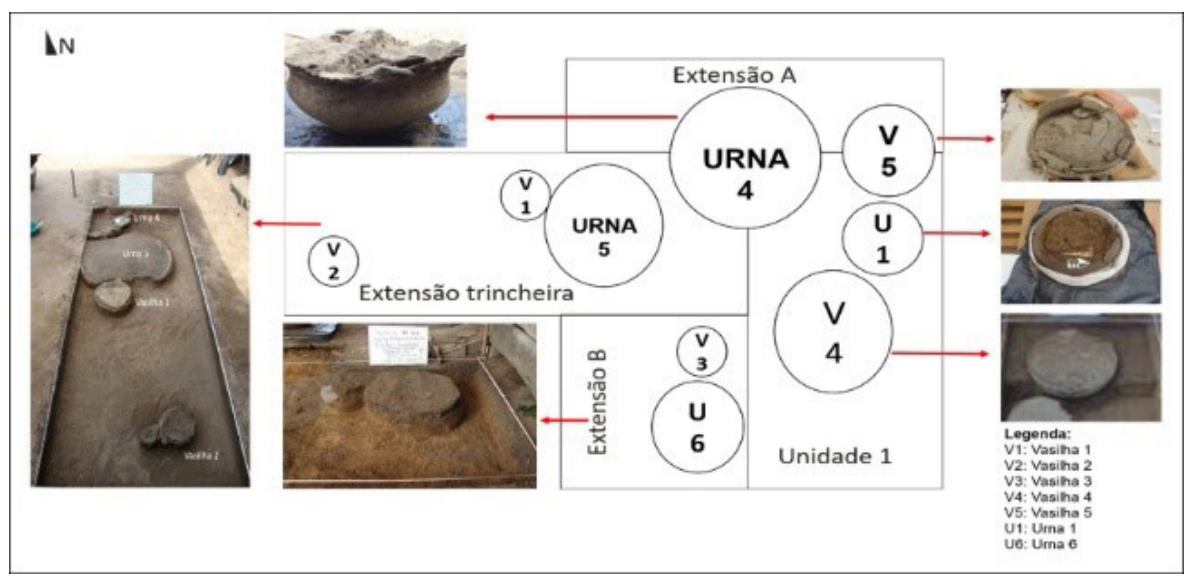

Figura 2 - Área de escavação 1 do sítio N.S.P. Socorro. 
A área de escavação 2 tem um leve declive em direção ao rio. Essa área está limitada por um barranco de aproximadamente $13 \mathrm{~m}$ de altura em relação ao rio na estação seca, podendo existir variação e diminuir com a cheia do rio. A escavação 2 teve como intenção investigar a presença de uma vasilha grande aflorando na superfície, aproximadamente $27 \mathrm{~m}$ a sudeste da área de escavação 1 , neste local existe grande quantidade de árvores frutíferas, principalmente mangueiras com raízes grandes e extensas (raízes superficiais). Foram abertas 5 unidades de escavação 1 x $1 \mathrm{~m}$ (unidades 1 a 5) e todas apresentavam perturbação por ações antrópicas.

De maneira geral as escavações realizadas nas três etapas renderam 1.577 fragmentos cerâmicos, 151 fragmentos líticos, três "vasilhas" cerâmicas e 12 supostas urnas funerárias. No campo, como forma de identificação e separação, dividiu-se o material em urnas ou vasilhas. As urnas foram nomeadas levando em conta o seu tamanho (maiores ou menores) e/ou a presença visível de fragmentos ósseos, todas as outras que não se encaixavam nas duas características foram nomeadas como vasilhas. Após a retirada e classificação dos materiais, foi realizada uma ligeira limpeza de superfície, retirando o sedimento aderido ao corpo das urnas/ vasilhas para que fossem então embaladas para transporte.

Observou-se que as urnas e vasilhas, mesmo antes das escavações, haviam sofrido processo de degradação acentuado, com vários "traumas" no material, muitos de origem tafonômica, com quebra das paredes pelo deslocamento das raízes no interior e exterior das urnas e vasilhas, intervenções antrópicas podem até mesmo ter destruído o material osteológico no interior de algumas urnas.

As urnas e vasilhas escavadas no sítio estavam enterradas em solo bastante argiloso e compacto, possivelmente situadas abaixo da camada original de ocupação. Também foi constante nas escavações a ausência de vestígios materiais diferenciados no entorno ou misturados ao sedimento.

Quando chegou ao fim a escavação do Sítio Nossa Senhora do Perpétuo Socorro, todo o material resgatado foi enviado para o laboratório de Arqueologia da Universidade Federal do Pará. Para este artigo foram escavadas nove das 12 urnas e duas das três vasilhas coletadas $^{1}$. As escavações permitiram inferências sobre a ocupação do sítio e sobre as práticas de sepultamento.

\section{4 - MATERIAIS E MÉTODOS 2}

$\mathrm{Na}$ pesquisa e produção do artigo, a metodologia utilizada consistiu inicialmente no registro fotográfico e descrição do material após retirada da reserva técnica para o seu manuseio. Utilizou-se uma ficha de escavação onde era possível descrever as primeiras impressões sobre a urna e/ou vasilha, o modo de acondicionamento, as medições e observações complementares, como a existência ou não de materiais visíveis junto ao sedimento.

No segundo momento foi retirado o material que envolvia e protegia as vasi- 
lhas e/ou urnas, o material oriundo de cada vasilha era identificado com números sequenciais de acordo com sua procedência de campo. Desta forma, uma urna e/ou vasilha com numeração de campo, terá as observações seguindo uma ordem crescente .1; .2; .3 em diante. Assim, as informações na ficha de escavação ficariam: Urna 1.1; Urna 1.2; Urna 1.3...1.57; onde o primeiro número corresponde a identificação da urna e/ou vasilha, e o segundo refere-se à observação.

As escavações em laboratório foram realizadas em níveis artificiais de $5 \mathrm{~cm}$, retirando amostras de $100 \mathrm{~g}$ de sedimento a cada término de nível como amostra para análise de solo. Para as referências de altura, quando necessário, foram usados pontos fixos que pudessem servir como DATUM, marcando nas fichas de escavação o ponto e o modo como as urnas ou vasilhas estavam orientadas no momento da escavação.

Ainda sobre os níveis artificiais, observou-se que dependendo da necessidade seria desenhado o croqui da base do nível. Caso não fosse necessário o croqui, segue-se com o fechamento da ficha de nível e inventário do material recolhido, separando estes (lítico, cerâmica, fragmento de osso, carvão, ecofatos e outros) e armazenando-os em caixas arquivo, já identificados e etiquetados. As fotos referentes a escavação foram divididas por nível de escavação. Para a identificação e análise de material osteológico e biológico foram utilizados alguns manuais de osteologia e conservação como: Pereira \& Mello-Alvim (1978); Neves (1988); Lagunas (2000); Krogman \& Iscan (2003); Whi- te \& Folkens (2005); Krenzer (2006); Ubelaker (2008); Schaefe et al. (2009); Lessa (2011).

\section{5 - PRÁTICAS FUNERÁRIAS NO SÍ- TIO NOSSA SENHORA DO PERPÉ- TUO SOCORRO}

É fato a importância das práticas mortuárias para as comunidades pretéritas e os estudos relacionados ao tema da morte não são recentes, vem da tradição antropológica, relacionando processos funerários a conceitos sobre religião e religiosidade. Não é de hoje o comportamento do ser humano temente a morte, provavelmente como resultado de um comportamento instintivo, que levaria o ser humano a não enfrentar a ideia de fim completo, de aniquilação. Nesse sentido a ideia de espírito e da existência de um mundo espiritual não se separam, são intimamente ligados, a experiência com o transcendente faz o ser humano chegar à crença reconfortante de continuidade espiritual e na "vida" após a morte (Malinowski 2004[1925]).

Essa experiência com o transcendente através da religião ou religiosidade é base para a relação de temeridade entre o mundo dos mortos e o mundo dos vivos, principalmente quando o ser humano acaba fazendo uso de observações relacionados a sonhos, sombras e visões sobrenaturais para "animar" e dar sentido às diversas experiências no seu cotidiano (Hertz 1990, 2004[1917]; Robben 2004; Malinowski 2004[1925]). Tais experiências são o núcleo do animismo, efetivando a "verdade" emo- 
cional da natureza humana, o desejo de viver. Assim, os ritos de luto e o comportamento ritual que acontecem imediatamente após a morte, podem ser tomados como padrão de um ato religioso, relacionado de forma mais geral aos dogmas e estruturas religiosas, enquanto que a crença na imortalidade, na continuidade da vida e no mundo inferior, podem ser tomados como o protótipo de um ato de fé, que se forma de uma maneira localizada; como exemplo, há evidências relacionadas às diversas crenças em uma mesma religião, em locais e em espaços diferenciados a partir de um mesmo axioma religioso ou crença mágica (Malinowiski 2004[1925]).

Desta maneira, os atos de luto, no desespero de imitar o lamento, no tratamento do cadáver ou na sua disposição, cumprem uma função importante e possuem um valor considerável para todas as sociedades, como consciência social, significação, representação coletiva ou rito de passagem (Tylor 1920[1871]; Hertz 1990/2004 [1917]; Mauss 2003 [1926]; Van Gennep 2004[1909]). Essas ideias aparentemente generalistas estão inseridas nos estudos sobre práticas mortuárias na Amazônia, tanto no âmbito conceitual sobre a morte quanto sobre os processos que envolvem as obrigações e ritos que levantam uma série de interpretações que, alinhadas aos estudos antropológicos e arqueológicos, não deixam de ser perceptíveis na realidade local.

A partir do momento da morte, há obrigação moral para com o morto, segue-se então uma série de etapas fúnebres que alteram o cotidiano. As práticas de cuidado do corpo do falecido interferem no cotidiano dos indivíduos da comunidade, ora pelas práticas de manuseio do corpo para determinado ritual, ora devido às regras lutuosas do contexto funerário dessas comunidades. As obrigações do grupo para com o indivíduo morto podem ser entendidas como atos diferenciados que são importantes na constituição dos laços sociais, na reafirmação de sua cultura, na consciência coletiva e na reafirmação de identidades, em especial quando os falecidos têm destaque social (um xamã ou líder e seus aparentados próximos).

Geralmente, as práticas mortuárias têm três momentos essenciais: o sepultamento dos restos mortais do falecido; a garantia de paz à alma no limiar entre o mundo dos vivos e dos mortos e, por fim, libertar a vida da comunidade das obrigações do luto, encerrando um ciclo social e cultural (Van Gennep 2004[1909]; Hertz 1990, 2004 [1917]).

$\mathrm{Na}$ Amazônia, as práticas mortuárias são importantes e acontecem de diversas maneiras nas muitas comunidades indígenas. Tais práticas dão margem a uma série de interpretações sobre o modo como essas populações pretéritas entendem os atos mortuários, sua relação com o mundo material e espiritual, que acaba justificando cada um à sua maneira, o modo como devem tratar o corpo dos indivíduos, sempre no afã de libertação das restrições pós-morte, assim como pela importância em homenagear o falecido.

As práticas funerárias acabam desempenhando um papel inegável também 
para os vivos, já que as práticas funerárias seriam a tradução material do ritual funerário, sendo essa prática o que sobra de acessível aos vivos hoje (Duday 2006: 47). Contrariamente, quando essa prática não se faz acessível, o que resta é tentar, através da leitura da cultura material e de informações as vezes vagas, inferir o que simbolizaria ou representaria a ação em determinado corpo, seu significado e o modo como se deu a prática funerária no contexto do sítio escavado, visando entender uma parcela daquele ato final.

A ação de sepultar fornece aos arqueólogos uma variedade de informações sobre as práticas funerárias do passado e uma ideia sobre os contextos sociais envolvidos nesse momento ritual, tendo em vista que até o ato de preparar o local para depositar os restos mortais de alguém é algo cuidadosamente pensado, envolvendo procedimentos que podem levar dias, meses ou mesmo anos em seu planejamento e execução. Assim sendo, a ação de inumação é um ato profundamente significativo com uma grande quantidade de significados (Pearsons 1999: 5).

Partindo desta perspectiva pretende-se vislumbrar considerações sobre os sepultamentos na Amazônia, em especial evidenciar os processos mortuários relacionados à região de Itaituba, as influências culturais, as redes de contato, as mudanças culturais, ideias e cosmologias que possam mostrar diversos aspectos das práticas mortuárias, percebendo também os agentes envolvidos nas ações sobre o corpo do falecido. Deve-se levar em conta que nessas comunidades indígenas o tratamento dos corpos também está relacionado à diferença de status, envolvendo idade, sexo e posição social (Martins 2012; Py-Daniel 2015).

Em levantamento feito por Py-Daniel (2015: 363-364) no que diz respeito às práticas funerárias nos relatos etnohistóricos, descrições etnográficas e história oral, têm-se a confirmação da grande diversidade de práticas funerárias existentes entre os falantes da língua Tupi, principalmente quando relacionados a ação direta sobre o corpo, a maioria dos sepultamentos são realizados em urnas, de forma primária (basicamente quando os esqueletos tem a persistência da conexão anatômica das articulações, entre outras características), secundária (onde o indivíduo é desarticulado e disposto de forma artificial sem articulação, podendo ter uma organização intencional a partir das interpretações funerárias de determinada comunidade) e ações diretas sobre o corpo como a queima/cremação (ação direta do fogo sobre o material funerário) de parte do cadáver ou do esqueleto.

\section{1 - Reclassificando urnas e vasilhas}

Para melhor organização das escavações e apresentação dos resultados foi feito uma distinção entre urna e vasilha tendo como critério o conteúdo em cada urna e/ou vasilha, considerando urnas funerárias os vasilhames que possuíam em seu conteúdo material osteológico, enquanto foram consideradas vasilhas aquelas que em seu interior não dispusessem material osteológico ${ }^{3}$, como apresentado na Tabela 1 (Chmyz 1966, 1969; 
Souza 1997). Desta maneira, uma classificação diferenciada da anterior (feita em campo) foi necessária. A nova classificação indicou um total de 7 urnas funerárias e 7 vasilhas, sendo que alguns dos vasilhames podem ser considerados acompanhamentos das urnas. As descrições seguiram a ordem crescente da nova atribuição, mesmo as que só pude- ram ser detalhadas a partir da comparação de fotos em campo e da forma das urnas, ou mesmo das vasilhas já em laboratório. A apresentação dos dados dividiu-se em dois momentos: 5.2 - Urnas e acompanhamentos e 5.3 - Vasilhas. Ao fim apresenta-se todas as urnas e vasilhas em uma única imagem (figura 4).

Tabela 1 - Dados e nova definição das Urnas e Vasilhas do Sítio N. S. P. Socorro

\begin{tabular}{|c|c|c|c|c|c|c|c|}
\hline $\begin{array}{l}\text { Nomenclatu- } \\
\text { ra de campo }\end{array}$ & $\begin{array}{l}\text { Diâm. } \\
(\mathrm{cm})\end{array}$ & $\begin{array}{l}\text { Alt. } \\
(\mathrm{cm})\end{array}$ & $\begin{array}{c}\text { Espessura } \\
\text { das paredes } \\
(\mathrm{cm})\end{array}$ & $\begin{array}{c}\text { Partes } \\
\text { conservadas }\end{array}$ & $\begin{array}{c}\text { Objetos } \\
\text { associados }\end{array}$ & $\begin{array}{c}\text { Presença } \\
\text { de } \\
\text { ossos }\end{array}$ & $\begin{array}{c}\text { Nova } \\
\text { definição }\end{array}$ \\
\hline Vasilha 1 & 22 & $*$ & $0,5-0,7$ & Parede & Não & Não & Vasilha 1 \\
\hline Vasilha 2 & 14 & 5.5 & $0,4-0,6$ & Base/Parede & Sim & Não & Vasilha 2 \\
\hline Vasilha 3 & 26 & 14 & $0,6-0,8$ & Base/Parede & Não & Não & Vasilha 3 \\
\hline Urna 1 & 55 & 19 & $0,6-0,8$ & Parede/Borda & Não & Sim & Urna 1 \\
\hline Urna 2 & 57 & * & $0,4-0,6$ & Parede/Borda & Não & Não & Vasilha 4 \\
\hline Urna 3 & 38 & 22 & $0,5-0,9$ & Parede/Borda & Não & Não & Vasilha 5 \\
\hline Urna 4 & 74 & 44 & $0,7-1,0$ & $\begin{array}{l}\text { Base/Parede/ } \\
\text { Borda }\end{array}$ & Não & Sim & Urna 4 \\
\hline Urna 5 & 65 & $*$ & $0,6-08$ & Parede/Borda & Não & Sim & Urna 5 \\
\hline Urna 6 & 32 & * & $0,5-0,8$ & Parede/Borda & Não & Sim & Urna 6 \\
\hline Urna 7 & 51 & 20 & $0,5-0,8$ & $\begin{array}{l}\text { Base/Parede/ } \\
\text { Borda }\end{array}$ & Não & Sim & Urna 7 \\
\hline Urna 8 & 30 & 23 & $0,5-0,8$ & Parede/Borda & Não & Não & Vasilha 6 \\
\hline Urna 9 & 30 & 23 & $0,5-0,7$ & Base/Parede & Não & Sim & Urna 9 \\
\hline Urna 10 & 64 & 20 & $0,6-0,8$ & Parede & Não & Não & Vasilha 7 \\
\hline Urna 11 & 64 & 20 & $0,5-0,8$ & Parede & Não & Sim & Urna 11 \\
\hline $\begin{array}{l}\text { Obs: } * \text { Sem } \\
\text { informações } \\
\text { sobre altura }\end{array}$ & & & & & & & \\
\hline
\end{tabular}

\section{2 - Urnas e acompanhamentos}

\section{Urna 1}

A Urna 1(Figura 4) é um vasilhame de formato globular deprimido, com estreitamento de abertura logo antes da borda extrovertida, com lábio arredon- dado. Não possui decoração, mas possui paredes alisadas, com antiplástico de cauixi. O diâmetro de abertura é de $55 \mathrm{~cm}$, a espessura da parede varia entre 0,6-0,8 cm e tem $19 \mathrm{~cm}$ de altura. Esta urna estava entre as vasilhas 5 e 4 (Figura 2) e foi retirada de campo em- 
borcada. Para sua retirada, foi deixado um pedestal de solo no seu fundo, que estava quebrado, preservando-se, dessa forma, o conteúdo do fundo (pedestal).

Essa urna estava fragmentada em várias partes, e os ossos em seu interior estavam muito friáveis, o que levou a serem consolidá-los com primal 5\% (1 água: 1 álcool). A escavação foi feita primeiramente no bloco de solo que estava aderido ao fundo da urna (pedestal) que soltou durante o transporte para o laboratório. Ao fim, escavou-se o corpo da urna, mantendo a posição emborcada como fora trazido de campo.

Foram encontrados vários ossos longos paralelos entre si no centro da urna, eram ossos longos deteriorados e sem as epífises, dificultando sua identificação, entretanto pela forma, tamanho e espessura, sugere-se serem tíbia, fêmur ou mesmo úmero.

Foram encontrados alguns fragmentos de dentes (nível $5-10 \mathrm{~cm}$ ) muito deteriorados e sem possibilidade de identificação, estavam juntos à concentração de ossos. Py-Daniel (2015: 236), quando iniciou a escavação dessa urna, observou que pelo tamanho do vaso, dos ossos, bem como pela disposição do material osteológico, existia a possibilidade do indivíduo ter sido colocado inteiro ou em pedaços ainda com as partes moles, apesar de não ter tido a oportunidade de verificar se havia algum tipo de disposição que mostrasse certa articulação entre os ossos; observou ainda que caso o indivíduo estivesse articulado no interior da urna, suas pernas estariam flexionadas logo abaixo dele.
Sobre sepultamento primário Ubelaker (2008: 56) nos fala que é importante perceber a existência de articulações, ligamentos ou outros tecidos. Já sobre as articulações, enfatiza que podem ser de dois tipos, a primeira seria uma articulação completa onde todos os ossos estão em posição correta anatomicamente e a segunda seria parcial onde alguns ossos estão em posição anatômica.

Caso existisse sepultamento primário no conjunto, basicamente teríamos que ter relações anatômicas entre os ossos muito claras, fator que não foi percebido (levando em conta a degradação do material). No entanto, ficou caracterizado um alinhamento dos ossos longos, paralelos ao fundo e no centro da urna, sem relação anatômica, indicando portanto uma organização intencional de ossos em sepultamento secundário. Não existem todos os ossos (pés e mãos, vertebras, crânio, pélvis, costelas, escápula e etc), o que pode remeter a possibilidade de escolha dos ossos a serem sepultados, fatores e observações que nos levam então a inferir um sepultamento secundário.

Tais práticas de sepultamento coincidem com o relato de Hartt (1885) sobre a presença de ossos e dentes em urnas funerárias, com ossos longos de membros superiores e inferiores alinhados de forma paralela e que não sofreram incineração. Dados etnográficos indicam a possibilidade de sepultamento de apenas alguns ossos do indivíduo quando de sua morte fora da aldeia. Hilbert (1958), por sua vez, nos informa que os sepultamentos escavados por ele basicamente eram secundários, com a presença de ossos 
longos, sem oferendas dentro ou fora das urnas. Também foram encontrados ossos pequenos muito aderidos ao sedimento, não identificáveis e dispostos de forma desorganizada por entre os ossos longos.

Ao fim da escavação ficou evidente à inexistência de base na urna, talvez porque nessas urnas a ausência de base remeteria a práticas simbólicas ligadas a morte dos vasos juntos com os indivíduos (Py-Daniel 2015: 302), já que poderíamos considerar a falta de base fator considerável para o desaparecimento dos vestígios osteológicos, simbolicamente também representaria um ato final.

Urna $4^{4}$

A Urna 4 (Figura 4) é um vasilhame de formato globular deprimido, formando antes da borda um estreitamento semelhante a um pescoço, para depois abrir, com bordas diretas e lábio arredondado. Não há decoração, as paredes são alisadas, antiplástico é de cauixi, possui um diâmetro de abertura de $74 \mathrm{~cm}, 44 \mathrm{~cm}$ de altura; a espessura das paredes varia entre 0,7 e 1,0 cm. Sua base é plana.

A urna possuía duas tampas, que estavam fragmentadas e haviam caído para dentro da urna. Assim como a urna, as tampas também possuem antiplástico de cauixi. No nível 0-5 cm, foi encontrada a primeira tampa com espessura entre $1,9-2,5 \mathrm{~cm}$, de formato circu- lar e quebrada em grandes fragmentos. O diâmetro dessa tampa é maior do que a boca da urna. Possui base plana com parede e borda formadas por apenas um ou dois roletes, sendo provavelmente um assador reutilizado (Py-Daniel 2015: 236). Após sua quebra, possivelmente no centro, a tampa acabou se acomodando junto às paredes da urna. Não chegou a se deslocar para o fundo, pois existia ali outra tampa, abaixo dessa primeira. A segunda tampa tem espessura de 1,3 - 1,9 cm (Figura 4) e estava no nível $15-20 \mathrm{~cm}$, também estava fragmentada. Abaixo da segunda tampa, apareceu uma quantidade considerável de fragmentos ósseos e alguns dentes.

Os fragmentos dentários foram as evidências que mais se preservaram nesse contexto, permitindo a identificação de determinados dentes. Durante a escavação em laboratório foi percebida a existência de três concentrações de sedimento contendo ossos e dentes, tais blocos foram nomeados $\mathrm{A}, \mathrm{B}$ e C. A concentração A evidenciou uma sequência de 6 dentes que correspondem aos $3^{\circ}, 2^{\circ}$ e $1^{\circ}$ molares, $2^{\circ}$ e $1^{\circ}$ prémolares e um canino, todos inferiores esquerdo (Figura 3). Os dentes possibilitaram a identificação de idade morte do indivíduo como superior a 20,5 anos; entretanto, a ausência de raiz nos dentes impossibilitou fazer alguma inferência mais precisa (AlQahtani 2010). 

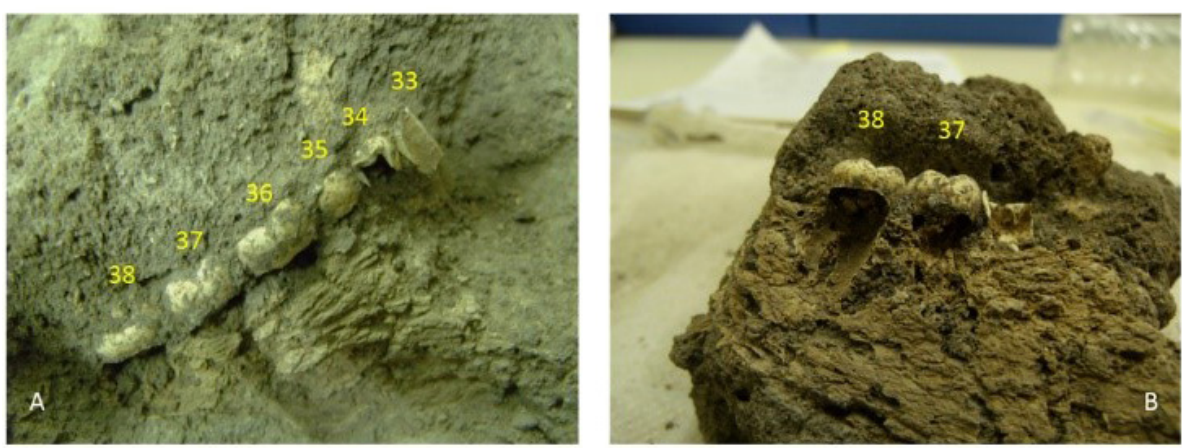

Figura 3 - Dentes urna 4: (A) Sequência de dentes - $3^{\circ}(38), 2^{\circ}(37)$ e $1^{\circ}(36)$ molares; $2^{\circ}$ (35) e $1^{\circ}$ (34) pré-molares e Canino (33); (B) Dentes utilizados para estimativa de idade a morte no mesmo bloco da figura A. Fotos: Diego Barros.

A identificação dos dentes foi feita de acordo com sistema FDI (Fédération Dentaire Internationale), e reconhecidos como 38, 37, 36, 35, 34 e 33 (Harris 2005: 45).

Existe uma boa quantidade de ossos junto a fragmentos dentários nos três blocos. Os dentes estavam tão frágeis que se quebravam facilmente a qualquer movimentação do sedimento na urna, muitas das vezes esfarelando-se. Os ossos nos blocos diferenciam-se, nos blocos A e C apareceram, em sua maioria, ossos menores que não podem ser identificados devido ao fato de estarem muito compactados ao sedimento, não permitindo sua escavação, pois, assim como os dentes, quebravam muito facilmente.

No bloco B, existiam três dentes, um molar possivelmente superior, um incisivo lateral e um incisivo central ambos inferiores. O molar superior está acima de um incisivo lateral inferior, fato que pode ser explicado pelo deslocamento dos dentes na movimentação do sedimento pela urna, não foi possível re- tirar os dentes inteiros e indicar a sua lateralidade.

Os ossos longos estão concentrados sobretudo no Bloco C, e assim como na urna 1 , aparentemente são tíbia, fêmur ou úmero, não podendo ser identificados de forma precisa já que não apresentam as epífises e sua forma não permite identificação visual confiável. O que parece ter acontecido nesse caso foi um rearranjo após o tratamento do corpo, pois os ossos longos não apresentam uma ordenação que se mostre articulado, estão alinhados um por cima do outro, o que caracterizaria, por essa perspectiva, um sepultamento secundário.

Os ossos alinhados e a existência de dentes se assemelham às descrições de sepultamentos encontrados por Hartt (1885) e Hilbert (1958). Hartt (1885) também menciona ter encontrado um sepultamento em urna que continha uma grossa chapa redonda de cerâmica sem decoração, posicionada de forma horizontal sobre a qual encontrou diversos ossos humanos de membros 
superiores e inferiores sem aparente incineração.

A coloração de alguns ossos encontrados nessa urna levanta a possibilidade de cremação. A cremação/ incineração é um processo de queima direta, que provoca alteração de coloração, podendo levar até a quebra ou pulverização (Duday 2006; Muller 2008; Andrews \& Bello 2009; Py-Daniel 2015). Apesar de não existir consenso sobre as temperaturas e colorações, pode ser feita uma aproximação (Ubelaker 2008: 57; Shipman 1989: 311; Müller 2008: 57-64).

Tabela 2 - Relações entre as cores dos ossos e temperatura de queima

\begin{tabular}{|c|c|c|c|}
\hline \multicolumn{2}{|c|}{ Mays, 1999} & \multicolumn{2}{|c|}{ Shipman et. al., 1984 (in MAYS, 1999) } \\
\hline Temperatura ${ }^{\circ} \mathrm{C}$ & Cor & Temperatura ${ }^{\circ} \mathrm{C}$ & Cor \\
\hline 185 & Vermelho/Laranjado & 285 & Branco ou amarelo \\
\hline 285 & Marrom escuro/Preto & $285-525$ & $\begin{array}{l}\text { Marrom avermelhado, } \\
\text { vermelho/amarelado. Cinza } \\
\text { escuro/marrom ou cinza escuro. }\end{array}$ \\
\hline 360 & Preto & $525-645$ & Preto, azul ou vermelho/amarelado \\
\hline 440 & Cinza) Marrom & $645-940$ & $\begin{array}{l}\text { Branco, cinza claro ou cinza azulado } \\
\text { claro. }\end{array}$ \\
\hline 525 & $\begin{array}{l}\text { Cinza/Marrom (mais } \\
\text { claro que a observada } \\
\text { em } 440^{\circ} \mathrm{C} \text { ) }\end{array}$ & 940 & $\begin{array}{l}\text { Branco, alguns cinza ou } \\
\text { vermelho/amarelado. }\end{array}$ \\
\hline $645-1200$ & $\begin{array}{l}\text { Branco, ou amarelo } \\
\text { palido }\end{array}$ & & \\
\hline
\end{tabular}

Fonte: Mays 1999: 217 in Müller 2008: 62.

Assim como a possibilidade de queima e o fato dos ossos estarem melhor conservados em relação aos da urna 1, a coloração amarelada dos vestígios ósseos, mesmo sem a ação do consolidante, com padrões de fratura transversais e quebras longitudinais irregulares, bem como craquelamentos, se assemelham a processos de cremação em ossos frescos ou com as partes moles (Ubelaker 2008: 57; Shipman 1989: 311; Müller 2008: 57-64). Existe ainda a presença de um fragmento de dente cremado, diferente do demais dentes, talvez por ter sofrido ação direta da fonte de calor.
De forma geral, existe a possibilidade do contexto ter sido o de uma cremação em baixa temperatura, como parte da prática de sepultamento secundário, reforçado por uma série de relatos (Hartt 1885; Metraux 1947; Horton 1948; Chaumeil 1997; Rostain 2011) sobre práticas funerárias mundurucu indicando o emprego da cremação e posterior sepultamento. No entanto não se pode excluir a ideia de sepultamento sem queima - apenas tendo sido realizado a decomposição -, levando em conta que a preservação ruim do material pode ter características semelhantes a cremação.

Schaan (2003:3) informa que na Amazônia existem uma série de indicações arqueológicas relacionadas às práticas de sepultamento secundário, que consistem basicamente na identificação de ossos desarticulados. Os sepultamentos duplos ou secundários são comuns nas sociedades pré-históricas e coadunam com a ideia de ritos de passagem, desta forma, o corpo do indivíduo permanece em um local provisório, que em muitos casos pode ser um vaso grande para que ocorra o processo de decomposição do corpo e em seguida precede-se da separação dos ossos (Hertz 1990; Schaan 2003).

Uma das formas de identificar essas práticas de decomposição nas urnas são furos em seu fundo, isso indicaria o uso da urna no processo de decomposição do corpo, sendo o furo preparado e por onde o líquido seria drenado, líquido resultante da decomposição (Schaan 2003:3). A base da urna 4 apresenta furo semelhante, especula-se então a utilização dessa urna para um 
processo de decomposição das partes moles e posterior reutilização para deposição dos fragmentos ósseos pós-queima em baixa temperatura, dando sentido ao aparecimento de dentes abaixo dos diversos ossos longos como fruto de arrumação intencional dos vestígios.

Os dados demonstram um tratamento diferencial a essa urna, tanto por ser uma das maiores do conjunto, quanto pelo modo como o corpo aparentemente foi manuseado, sendo uma das poucas urnas que tem base e apresenta evidências de furo intencional provavelmente feito após a queima da cerâmica, de dentro para fora, fazendo que parte da cerâmica se desprende-se no lado externo da base.

Tais indícios coadunam para a utilização dupla da urna, um primeiro momento para o depósito primário, possivelmente ainda em articulação de um indivíduo (ou partes dele), e um segundo uso após os ossos sofrerem queima ainda frescos em baixa temperatura, seguido da deposição final.

A idade a morte a partir dos dentes de um indivíduo, concluiu que se tratava de um jovem adulto (AlQahtani 2010), que possivelmente tinha grau de importância para a comunidade, pois até o momento essa foi a única urna que apresentou uma percepção de tratamento da morte diferenciado, o que demandaria um período "prolongado" nos processos rituais de sepultamento.

\section{Urna 5 e Vasilha 1}

A Urna 5 (Figura 4) é um vasilhame de contorno simples, raso, que tem formato aberto, não possui nenhum tipo de decoração externamente ou internamente, suas paredes são alisadas de forma regular, sua boca possui formato circular, borda direta e lábios arredondados, seu antiplástico é caco moído e cauixi, o seu diâmetro de abertura é de $65 \mathrm{~cm}$, não possui informações sobre a sua altura, a espessura da parede varia entre $0,6-0,8 \mathrm{~cm}$.

A urna fragmentou-se em três blocos de sedimento, nomeados A, B e C. O Bloco A, com $21 \mathrm{~cm}$ de altura, concentrava fragmentos cerâmicos em seu centro.

O Bloco B, com $18 \mathrm{~cm}$ de altura, era basicamente composto por sedimento, com alguns poucos fragmentos cerâmicos e um fragmento lítico. O Bloco C, com $22 \mathrm{~cm}$ de altura, também tinha em seu conteúdo sedimento, um possível osso longo, alguns fragmentos líticos e cerâmicos.

A ausência da base da urna pode ter contribuído para a deterioração do material osteológico, impossibilitando relacionar diretamente essa urna a algum tipo específico de prática mortuária. A urna é semelhante às urnas largas e rasas como panelas encontradas por Hartt (1885), na localidade de Cafezal, na margem esquerda do rio Tapajós.

Talvez, exista a possibilidade dessa comunidade ter feito um ritual de sepultamento apenas para uma parte do corpo, prática comum quando o indivíduo morria fora da aldeia, ação também relacionada aos índios Mundurucu. A ausência de um número maior de outros vestígios osteológicos e de fragmentos de dentes pode indicar essa possibilidade. Também não foram encontrados vestígios de ossos incinerados mistura- 
dos ao sedimento da urna, prática ritual também comum entre os Mundurucu. Existe ainda uma pequena vasilha ( $\mathrm{Va}-$ silha 1) que está associada à urna e que pode ser considerada como um acompanhamento.

A Vasilha 1, com $22 \mathrm{~cm}$ de diâmetro de boca, foi escavada em campo (Schaan 2010: 26). A espessura das paredes varia entre 0,5 e $0,7 \mathrm{~cm}$, não apresenta decoração interna ou externa, suas paredes são alisadas de forma irregular, seu antiplástico é de cauixi. Em campo a vasilha estava inteira, colada à urna 5 , um pouco acima, indicando a possibilidade de momentos de ocupação e/ou sepultamentos diferentes, até mesmo o uso do espaço por um período de tempo sem precisão, já que não existem datações para o sítio.

\section{Urna 6 e Vasilha 3}

A Unna 6 (Figura 4) é um vasilhame de formato semi-esférico, não possui decoração interna ou externa, suas paredes são alisadas de forma regular, seu antiplástico é de cauixi. Foi encontrada borda extrovertida com incisões no lábio em seu interior. A urna possui diâmetro de abertura de $32 \mathrm{~cm}$, mas não se sabe a altura. A espessura da parede varia entre 0,5 e $0,8 \mathrm{~cm}$, essa mesma parede da urna estava fragmentada e aderida ao sedimento do interior da urna.

A urna dividiu-se em dois blocos (A e B) que ao serem escavados consistiam basicamente de sedimento com alguns fragmentos cerâmicos em seu interior e poucos fragmentos ósseos deteriorados.

O Bloco A apresentou apenas parte do corpo e da borda junto ao sedimento, sem base.
O Bloco B mostrou um material muito diferente do que nas demais urnas, pois existia em seu interior uma porca de metal, pedaços de arame, pedras de seixo e uma tacha de metal. Apareceram fragmentos ósseos muito deteriorados, prejudicando a identificação precisa dos ossos. Muito próximo a essa urna existia a Vasilha 3, que pode ser um vasilhame de acompanhamento.

A Vasilha 3 (Figura 4) é a única no conjunto a possuir engobo vermelho na sua parte externa, representando possível grau de importância ao indivíduo. A urna tem formato semi-esférico, paredes alisadas com engobo vermelho, as bordas estão faltando e o antiplástico é o cauixi, seu diâmetro de abertura equivale a $26 \mathrm{~cm}$ e foi medido em campo como se fosse a borda. Tinha $14 \mathrm{~cm}$ de altura, a espessura de sua parede varia entre 0,3 e $0,5 \mathrm{~cm}$.

Também estava localizada perto da saída da cozinha da residência, contudo não apresentou material histórico em seu interior. Existiam possíveis fragmentos ósseos que não puderam ser identificados, pois estavam muito deteriorados e compactados ao sedimento, impedindo inclusive perceber que tipo de ossos tratavam-se, seu tamanho, se foram cremados ou não, pareciam até mesmo estarem triturados.

A vasilha em questão se assemelha às vasilhas descritas por Hilbert (1958: 11) principalmente pelo engobo vermelho na parte exterior, que apesar de encontrar as urnas em área de influência dos Mundurucu, não acredita que sejam referentes a esse povo, pois trabalha com a ideia de serem ocupan- 
tes relativamente recentes da região do Tapajós, apesar dos mesmos viverem nas áreas das missões naquele momento, afirmando que não reconhecem o material, as técnicas decorativas e as práticas como sendo referente a eles.

Hilbert (1958: 4-5) menciona uma urna que foi utilizada para o enterro de uma criança, quando alguns fragmentos da própria urna foram usadas como tampa; os ossos em seu interior estavam esfarelados, ao lado dessa urna existia uma segunda urna muito quebrada e sem fundo, descrição que coincide guardada as devidas comparações de tamanho com as Urna 6 (sem base) e Vasilha 3.

O antiplástico também coincide com algumas vasilhas análisadas por Hilbert (1958: 6-9), com grande quantidade de cauixi. Hilbert (1958) acredita que essas urnas funerárias pertençam a ocupações indígenas anteriores e culturalmente diferentes dos Mundurucu históricos, chega a dizer que não conheciam a prática de sepultamento secundário, assim como utilizavam o caraipé como antiplástico, como faziam os Mundurucu do rio Cururú. Nesse caso, nada podemos confirmar como sendo uma cerâmica tipicamente Mundurucu para essa vasilha, apesar de Py-Daniel (2015: 244) informar existir um estudo que vislumbra a possibilidade de uma ocupação Mundurucu mais antiga às margens do rio Tapajós, na região de Itaituba (Hilbert 1958; Martins 2012c; Py-Daniel 2015).

\section{Urna 7}

A Urna 7 (Figura 4) é uma vasilha de base reta, carenada, com pequeno e discreto pescoço de borda extrovertida. Há decoração com incisões apenas no lábio, o restante da vasilha é apenas alisado. $O$ antiplástico é de cauixi. Possui $51 \mathrm{~cm}$ de diâmetro de abertura, mede $20 \mathrm{~cm}$ de altura, a espessura da parede varia entre 0,5 e $0,8 \mathrm{~cm}$.

A urna estava aflorando na superfície e apresentava uma série de raízes que quebraram suas paredes e a atravessavam. Para a retirada da urna foi necessário cortar as raízes. Existia uma tampa que estava quebrada em vários pedaços, sua espessura varia entre 0,9 e $1,2 \mathrm{~cm}$, e estava misturada junto aos fragmentos da própria urna como na urna 4 abaixo, do nível $10-15 \mathrm{~cm}$ foram verificados fragmentos ósseos triturados e dispersos bem compactados ao sedimento.

Na literatura e nos relatos etnohistóricos, é comum a prática de sepultamento secundário de cinzas, em especial o esqueleto de pessoas de alta posição, onde após o processo de descarne feito pelo grupo, queimavam seus ossos e a cinza era enterrada em urnas (Metraux 1947; Horton 1948; Hilbert 1958; Chaumeil 1997; Rostain 2011; Py-Daniel 2015). Hartt (1885) também descreve ter encontrado algumas urnas com fragmentos de ossos misturados à terra preta, ele teve a percepção de que os fragmentos teriam sido incinerados. A tampa pode reforçar a ideia de o indivíduo ter sido uma pessoa importante para a comunidade, já que somente em duas urnas foram encontradas tampa; para além disso é a única urna que se pode dizer ter material triturado, algo diferente das outras urnas, coincidindo 
com as informações de ossos esfarelados em urnas.

Outra observação refere-se à existência de fragmentos no interior da urna que pertenceriam a Vasilha 6, que estava próxima à urna 7 , possivelmente por um deslocamento da cerâmica pela ação das raízes que estavam presentes nas duas urnas.

\section{Urna 9}

A Urna 9 (Figura 4) tem contorno simples com formato globular, não possui decoração, as paredes são alisadas de forma regular, a borda estava ausente, a constituição do seu antiplástico é de cauixi, possui $30 \mathrm{~cm}$ de diâmetro de abertura, $23 \mathrm{~cm}$ de altura, e a espessura da parede varia entre 0,5 e $0,7 \mathrm{~cm}$.

Em campo a urna estava aflorando como as outras, existiam raízes que a atravessavam e causaram diversas fraturas nas paredes, também foi necessário cortar as raizes e envolver a urna com atadura e plástico filme para que não desmontasse ainda em campo.

No laboratório, a urna apresentou fragmentos de ossos longos no nível $15-20 \mathrm{~cm}$. Os ossos localizavam-se no centro da urna e ao fundo. Como nas Urnas 1 e 4, o sedimento que envolvia os ossos aderiu de forma significativa ao material ósseo, dificultando a escavação e o detalhamento dos ossos. Os ossos longos estavam arrumados de forma paralela entre si, posicionados no fundo da urna, por cima da base, sendo esta o base fator que contribuiu para a conservação parcial do material.

Nessa urna foi possível evidenciar uma costela (Lagunas 2000; Krogman 2003; White e Folkens 2005; Krenzer 2006;
Skhaefer e Scheuer 2009) abaixo dos ossos longos, não apresentava organização que a caracterizasse em articulação, remetendo a um sepultamento secundário.

Também foi encontrado aos $15 \mathrm{~cm}$ de escavação uma base emborcada. Hilbert (1958), quando descreve uma das urnas encontradas por ele, informa sobre uma técnica de enterramento "improvisado", onde colocam o fundo de uma outra vasilha com a intenção de ser uma tampa protetora, separando os fragmentos ósseos do contato com o solo.

O termo improvisado me parecer ser indevido, já que as práticas de sepultamento têm uma clara intencionalidade. O reaproveitamento de fragmentos cerâmicos pode ter sentidos diferenciados da ação de "improvisação", pois as práticas funerárias demandam tempo e dedicação (Pearsons 1999).

\section{Urna 11}

A urna 11 (Figura 4) tem contorno simples com formato globular, e pequeno estreitamento antes da borda direta. Não possui decoração interna ou externa, mas suas paredes são alisadas. A borda estava ausente, a não ser por uma pequena parte junto ao corpo inferior. O antiplástico é de cauixi. Tem altura de $20 \mathrm{~cm}$, e a espessura da parede varia entre 0,5 e $0,8 \mathrm{~cm}$.

Esta urna tinha uma série de perturbações relacionadas a raízes, suas bordas foram totalmente destruídas e a parede sofreu uma série de quebras, existiam raízes em seu interior, o sedimento estava muito compacto. Foi possível verificar a presença de fragmentos de ossos muito deteriorados 
entre o nível 10-15 cm, impossível de reconhecer forma ou mesmo o tipo de osso, aparentemente estavam triturados.

O fato dessa urna não ter base, tampa e estar com a borda totalmente quebrada, pode explicar que a intensa ação do ambiente sobre a urna não permitiu a conservação de maior quantidade de material osteológico ou algum fragmento dentário. A possibilidade então para essa urna é de materiais ósseos triturado assim como na Urna 7, já que os fragmentos ósseos estavam espalhados pela urna e muito compactados ao sedimento, tratando-se também de um sepultamento secundário.

\section{3 - Vasilhas}

\section{Vasilha 2}

A Vasilha 2 (Figura 4) possui um contorno simples, com base plana, corpo inferior cônico e corpo médio arredondado, com borda ausente. Não possui decoração e suas paredes são alisadas de forma regular. A inclinação interna das paredes pode indicar uma boca contraída. O antiplástico é de caco moído e cauixi, possui $14 \mathrm{~cm}$ de diâmetro de abertura e 5,5 $\mathrm{cm}$ de altura.

Essa vasilha estava na extensão trincheira, junto a ela encontrava-se uma pequena vasilha decorada, pertencente à tradição inciso ponteada, também com formato arredondado, com base plana, ponteados sobre o corpo e apliques zoomorfos junto à borda. A escavação da vasilha 2 , feita em laboratório, ocorreu em um único nível de $5 \mathrm{~cm}$, não apresentando nada além de sedimento em seu interior.
A vasilha na perspectiva das práticas funerárias é interessante, pois além de ser um vasilhame pequeno, tem junto um pote menor e decorado. Os acompanhamentos podem ter diferentes funções e significados, entre estas, ter contido "alimento" para o morto.

Levando em conta a inexistência a nível macroscópico de evidências osteológicas ou mesmo de material triturado junto ao sedimento, é possível para esse tipo de sepultamento a substituição do próprio corpo do morto por objetos, o que é comum para alguns grupos amazônicos (Chaumeil 1997; Py-Daniel 2015), sendo a vasilha uma representação do indivíduo falecido. Por outro lado, essas vasilhas podem ser acompanhamentos das urnas (4 e 5) encontradas na mesma unidade, apesar de não estarem tão próximas. Não se tem relatos de sepultamentos de vasilhas como substitutivas de corpos para a região de Itaituba, contudo é uma possibilidade a ser considerada devido a intensa dinâmica cultural existente nessa região através de algum contato com outro grupo indígena.

\section{Vasilha 5}

A vasilha 5 (Figura 4) tem contorno simples, com formato semi-esférico, com pequeno estreitamento antes $\mathrm{da}$ borda extrovertida e lábio com incisões. Não possui decoração, suas paredes são alisadas de forma regular; seu antiplástico é de cauixi. Esta vasilha mede $38 \mathrm{~cm}$ de diâmetro de abertura e $22 \mathrm{~cm}$ de altura, a espessura da parede varia entre $0,5-0,9 \mathrm{~cm}$.

Essa vasilha não tem base, pois sofreu em campo uma série de quebras devi- 
do ao fato da urna 1 ter sido depositada um pouco acima dela. Estava perto das urnas 1, 2 e 4. No interior havia uma série de fragmentos da própria vasilha.

Essa vasilha se assemelha na forma e no tamanho às demais do sítio. $\mathrm{Na}$ escavação dessa vasilha não foram encontrados fragmentos de dentes ou ossos.

\section{Vasilha 6}

A vasilha 6 (Figura 4) tem contorno simples, com formato globular deprimido, pescoço convexo, borda extrovertida, lábio apontado. A borda possui decoração digitada. Possui antiplástico de cauixi, mede $30 \mathrm{~cm}$ de diâmetro de abertura, $23 \mathrm{~cm}$ de altura.

A vasilha foi encontrada após a abertura da unidade 2 para a retirada da urna 7. Em campo estava fragmentada e quebrada por raízes próximas e foi embalada com atadura e plástico filme para evitar a quebra total. Em laboratório apresentou basicamente sedimento e fragmentos cerâmicos das paredes e alguns fragmentos de borda.

Essa vasilha não apresentou ossos em seu interior, sendo a ação das raízes assim como a ausência de base fatores que podem ter contribuído com o desaparecimento dos possíveis vestígios ósseos.

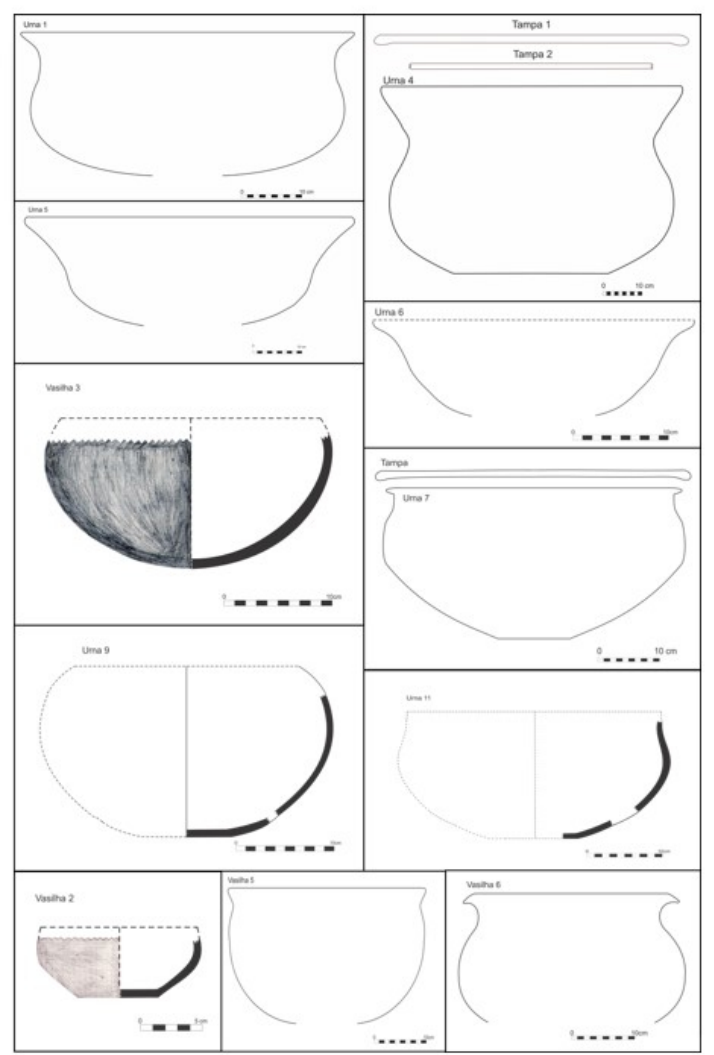

Figura 4 - Formas das urnas e vasilhas 


\section{6 - CONSIDERAÇÕES FINAIS}

A pesquisa mostrou uma série de tratamentos para os restos mortais, sobretudo sepultamentos secundários de ossos inteiros, ossos triturados ou mesmo cremados.

Nesse universo de materiais investigados, existem materiais líticos lascados e polidos, machados polidos e lascas de sílex, recolhidos sobretudo na superfície. Existe um total de 18 machados: seis inteiros, nove machados fragmentados e três fragmentos avulsos. Uma das lâminas de machado foi encontrada associada a urna 4, tinha desgaste por uso, sugerindo a prática de sepultar também os objetos pertencentes aos indivíduos (Martins et al. 2010; Araujo da Silva 2013), o que reforçava a ideia desta urna ser a mais complexa do conjunto.

Para, além disso, a urna 4 mostrou-se interessante na interpretação mais ampla sobre a complexidade dos processos mortuários, não enquadrando de forma linear um sepultamento a determinada prática sobre o corpo como sendo primária ou secundária, revelando a presença de um contínuo e elaborado ato funerário, indo além da classificação e descrição de um processo aparentemente imutável.

Sobre a queima, ao que parece, foi em baixa temperatura, reforçando um sepultamento secundário, muito pela coloração dos ossos e quebras significativas referentes a essa ação sobre o osso.

O sítio parece ter funcionado parcialmente como um cemitério, o modo de deposição das urnas mostram uma sequência de eventos durante certo tempo, onde algumas urnas e vasilhas foram enterradas em momentos diferentes (caso da vasilha 1), que fora depositada acima da urna 5 , indiciando a priori o uso do espaço periodicamente.

Para o conjunto de urnas, ficou claro que as urnas com base conseguem preservar melhor o material osteológico, enquanto as que não possuem mostraram pouco ou nenhum vestígio ósseo, apesar de a urna 1 ser uma exceção.

Boa parte dos escritos falam sobre vários modos de sepultamento para os índios Mundurucu, e quase todos terminam com a trituração dos ossos, no entanto essas urnas mostram um esforço para o ato da sua deposição no cemitério, próximo ou longe da comunidade, sem trituração dos ossos na maioria dos casos.

Esse espaço cemitério parece ser dos índios Mundurucu, sobretudo pelas aproximações com dados da etnografia ou mesmo as descrições relacionadas à sua ocupação nas margens do rio Tapajós, relatos que remontam no mínimo aos últimos 200 anos, coincidindo com a diversidade de práticas rituais e de sepultamentos secundários. Py-Daniel (2015: 386-387) estima que as urnas do sítio datem do século $\mathrm{X}$ ao século XVII.

É comum nos relatos o tratamento diferenciado para determinados indivíduos nas comunidades indígenas, existindo a possibilidade de ocorrer um tratamento funerário mais destrutivo, como nas urnas que apresentaram material triturado. A possiblidade de enterro de urnas sem base ser intencional, demonstram tratamentos diferentes ou circunstâncias sociais e políticas que 
determinem o tipo de sepultamento a ser realizado, fica a cargo das escolhas culturais os tipos de regras que irão reger tais comportamentos.

Além do mais, a escavação mostrou o quanto é complexa a classificação de um sepultamento, pois pensar de forma estanque uma classificação dual (primária e secundária) que é bem sucedida em enterramento diferentes da Amazônia, sobretudo na Europa, por exemplo, e importado ao nosso contexto local, acaba deixando de vislumbrar um ato simbólico mais complexo, não dando conta de entender o que de fato ocorre no sítio, pois a diversidade é enorme e as modificações no espaço são realizadas constantemente.

Por fim, a dinâmica cultural é intensa, existe uma série de redes de contatos que possibilitariam explicar as mudanças rituais e simbólicas em curto espaço de tempo, sem a preocupação em deixar rastros de uma história linear e bem "contada" para a ciência e para os arqueólogos que tentam olhar o passado com o filtro do presente, limitando interpretações plausíveis sobre a realidade estudada. Essa pesquisa mostra também que apesar dos poucos dados sobre as práticas de sepultamento para a região e pelos poucos materiais encontrados, é possível relacioná-los com a etnografia e com os dados sobre práticas mortuárias referentes a uma etnia indígena, fator importantíssimo, pois o discurso de invisibilidade/ausência do material funerário na Amazônia não se sustenta e muito menos deve ser pressuposto para os atos funerários deixarem de ser estudados, muito pelo contrário, deve servir de estímulo a inclusão do tema para o entendimento mais amplo da complexidade de um sítio arqueológico, tirando o foco apenas da cerâmica como representante direto das interpretações sobre o sítio.

\section{NOTAS}

${ }^{1}$ Vale destacar que parte dessas urnas foram escavadas no curso de Extensão de Escavação em Urnas Funerárias Arqueológicas realizado no período de 19 a 30 de março de 2012, no próprio Laboratório de Arqueologia da UFPA, ministrado pela professora Dra Anne Rapp Py-Daniel, algumas finalizadas e outras não, logo parte dos dados utilizados são desse período, inclusive alguns dados também foram citados em sua tese (Py-Daniel 2015). Não foram escavadas para essa pesquisa as urnas 2,10 e a vasilha 1 . Tais urnas e vasilhas já estavam desmontadas e armazenadas em caixas arquivo. Outra urna chamada em campo de 12 também foi encontrada no sítio, mas foi escavada pela equipe do laboratório da UFOPA - Universidade Federal do Oeste do Pará.

${ }^{2}$ A metodologia basicamente segue o proposto no curso de Extensão de Escavação em Urnas Funerárias Arqueológicas realizado no período de 19 a 30 de março de 2012, no próprio Laboratório de Arqueologia da UFPA, ministrado pela professora Dr ${ }^{a}$ Anne Rapp Py-Daniel.

${ }^{3}$ Deve-se destacar que o autor utilizou tal sistemática de renomeação para dar destaque aos vasilhames com ossos, tendo consciência que a ausência de material osteológico em contextos de pouca ou diferencial preservação não indicam que não possam ser urnas funerárias, contudo, no momento pareceu ser a melhor opção para tratar os dados obtidos.

${ }^{4}$ As urnas 2 e 3 foram renomeadas como vasilhas e serão descritas depois. 


\section{REFERÊNCIAS}

Acunã, C. 1994 [1641]. Novo descobrimento do grande rio das Amazonas. Uruguai: Oltaver S.A. Buenos.

Alqahtani, S. J; M. P. Hector; H. M. Liversidge. 2010. Brief communication: the London atlas of human tooth development and eruption, in American Journal of Physical Anthropology 142(3): 481-490.

Andrews P. \& Bello, S. 2009. Pattern in Human Burial Practice, in Social Archaeology of Funerary Remains Editado por Rebecca Gowland e Christopher Knüsel, pp. 14-29. Oxford: Oxbow Books.

Araujo da Silva, T. S. 2013. Construindo histórias: cadeia operatória e história de vida dos machados líticos amazônicos, in Revista de Arqueologia (Sociedade de Arqueologia Brasileira. Impresso) 25(1): 58-88.

Barbosa Rodrigues, J. 1875. Exploração e estudo do Valle do Amazonas e rio Tapajós. Rio de Janeiro: Typographia Nacional.

Bates, H. W. 1979. Um naturalista no rio Amazonas. Belo Horizonte: Itatiaia.

Bettendorf, J. F. 1909 [1698]. Crônica da missão dos padres da companhia de Jesus no estado do Maranhão [1625 - 1698], in Revista do Instituto Histórico e Geográfico Brasileiro 119.

Chaumeil, J. 1997 - Entre la Memoria y el Olvido. Observaciones sobre los ritos funeraios en las tierras baja de América del Sur, in Boletin de Arqueología PUCP. p. 207232.

Chmyz, I. 1966. Terminologia arqueológica brasileira para a cerâmica. Centro de Ensino e Pesquisa Arqueológica, in Manuais de Arqueologias parte I (1). Curitiba.

1969. Terminologia arqueológica brasileira para a cerâmica. Centro de Ensino e Pesquisa Arqueológica, in Manuais de Arqueologias parte II (1). Curitiba.
Coudreau, H. A. 1977. Viagem ao Tapajós. São Paulo: Itatiaia.

Duday, H.; P. Courtaud; E. Crubezy; P. Sellier; A. Tillier. 1990. L'Anthopologue "de terrain": onnaissance et interprétation des gestes funéraires, in Bulletins et Mémoires de la Société d'anthropologue de Paris - Nouvelle Série 2 (3-4): 29-49.

Duday, H. 2006. L' archeothanatologie ou l'archeologie de la mort (Archaeoetnoanatology of the archaeology of death), in Social Archaeology of funerary remains Editado por Gowland, R. e Knüssel, pp. 30-56. Oxford.: Oxbow Books

Dupras, T. 2011. Forensic recovery of buman remains: Archaeological approaches. New York: CRC Press.

Fairgrieve, S. I. 2008. Forensic cremation recovery and analysis. New York: CRC Press.

Florence, H. 2007. Viagem fluvial do Tietê ao Amazonas de 1825 a 1829. Brasília: Senado Federal, Conselho Editorial 93.

Gennep, A. V. 2004[1909]. The rites of passage, in Death, Mourning, and Burial: a cross-cultural reader.

Editado por A. C. G. M. Robben, pp. 213223. Oxford, United Kingdom: Blackwell Publishing.

Harry, E. F. 2005. Tooth coding system in the clinical dental setting, in Dental Anthropology 18(2): 44.

Hartt, C. F. 1885. Contribuições para a ethnologia do Valle do Amazonas, in Archivos do Musen Nacional 6:1-174.

Heriarte, M. de. 1962. Descriçam do estado do Maranbam, Para, Corupa, rio das Amazonas. Viena: Carlos Gerold.

Hertz, R. 1990[1917]. La muerte y la mano derecha. Madrid: Alianza Editorial. 2004[1917]. A Contribution to the Study of the Collective Representation of Death, in Death, Mourning, and Burial: 
a cross-cultural reader. Editado por A. C. G. M. Robben, pp. 197-212. Oxford, United Kingdom: Blackwell Publishing.

Hilbert, P P. 1958. Urnas funerárias do Rio Cururú, Alto. Tapajós, in Boletim do Museu Paraense Emilio Goeldi, Nova Série Antropologia 6: 1-13.

Horton, D. 1948. The Mundurucu, in Handbook of South American Indian 1(3): 271-282.

Krenzer, U. 2006. Compendio de Métodos Antropológicos Forenses para la Reconstrucción del Perfil Osteo-biológico - Tomo IV, in Serie de Antropología Forense. Guatemala: Centro de Análisis Forense y Ciencias Aplicadas. 121p.

Krogman, W. M \& M. Y. Isçan. 2003. The Human Skeleton in Forensic Medicine. Springfield: Charles C. Thomas.

Lagunas, R, Z. 2000. Manual de osteología antropológica. Instituto Nacional de Antropología e Historia.

Lessa, A. 2011. Conceitos e métodos em curadoria de coleções osteológicas humanas, in Arquivos do Museu Nacional 68(1-2): 3-16.

Malinowski, B. 2004[1925]. Magic, Science and Religion, in Death, Mourning, and Burial: a cross-cultural reader. Editado por A. C. G. M. Robben, pp. 19-22. Oxford, United Kingdom: Blackwell Publishing.

Martins, C P. 2010. Ocupações humanas pré-coloniais na bacia do baixo rio Tapajós, Amazốnia brasileira. Monografia de Especialização. Universidade Federal do Pará, Belém.

2012a. Sobre contatos e fronteiras: um enfoque arqueológico, in Revista Amazônica 4(1): 150-184.

2012b. Os moradores do centro: Ocupações indígenas pré-coloniais no baixo Tapajós, in Arqueologia, patrimônio e multiculturalismo na beira da estrada: Pesquisando ao longo das Rodovias Transamazônica e Santarém-Cuiabá, Pará. Editado por D. P. Schaan. Belém: JKNoronha.

. 2012c. Arqueologia do Baixo Tapajós: Ocupação Humana da periferia do domínio Tapajônico. Dissertação de Mestrado. Universidade Federal do Pará, Belém.

; D. P. Schaan; A. M. A. Lima, I. A. Bezerra \& W. F. S. Silva. 2010. Padrões de sepultamento na periferia do domínio Tapajó, in Revista Amazônica 2(1):167-171.

Mauss, M. 2003[1926]. Efeito Físico no indivíduo da ideia de morte sugerida pela coletividade (Austrália, Nova Zelândia), in Sociologia e Antropologia. São. Paulo: Cosac \& Naify.

Mendonça de Souza, S. M. F; C. Rodrigues-Carvalho. 2013. 'Ossos no chão': para uma abordagem dos remanescentes humanos em campo, in Boletim Museu Paraense Emílio Goeldi. Ciências Humanas 8(3)551-566. Disponível em: http://dx.doi.org/10.1590/ $\underline{\text { S1981-8122201300030 0005. Acesso em }}$ 10 jun. 2014.

Menéndez, M. A. 1981-82. Uma contribuição para a etno-história da área Tapajós-Madeira, in Revista do Musen Paulista 28: 289-389.

Métraux, A. 1947. Mourning rites and burial forms of the South American Indians, in América Indígena 7(1):7-44.

Müller, L. M. 2008. Sobre indios e ossos: estudo de três sitios de estruturas anelares construídos para enterramento por populacoões que habitavam o vale do rio Pelotas no período pré-contato. Dissertação de mestrado em História. Pontifícia Universidade Católica do Rio Grande do Sul, Porto Alegre.

Neves, W. A. 1988. Uma proposta pragmática para cura e recuperação de coleções de esqueletos humanos de origem arqueológica, in Boletim do Museu Paraense Emilio Goeldi-Zoologia 4:3-26. 
Nimuendajú, C. 1949. Os Tapajó, in Boletim do Museu Paraense Emílio Goeldi 10:93-106. . 1981[1947]. Mapa Etno-Histórico de Curt Nimuendajú. Rio de Janeiro: IBGE. 2004. In pursuit of a past Amazon: archaeological researches in the Brazilian Guyana and in the Amazon region. Editado por Per Stenborg. Ethnological Studies 45.

Pearson, M. P. 1999. The archaeology of death and burial. Phoenix Mill, UK: Sutton.

Pereira, C. B \& M. C. Mello-Alvim. 1978. Manual para estudos craniométricos e cranioscópicos. Rio de Janeiro.

Perota, C. 1979. Projeto PRONAPABA. Relatório de Campo. Vitória: Universidade Federal do Espírito Santo. Inédito.

Py-Daniel, A. R. 2009. Arqueologia da morte no sitio Hatahara durante a fase Paredão. Dissertação de Mestrado. Museu de Arqueologia e Etnologia, Universidade de São Paulo, São Paulo

2015. Os contextos funerários na arqueologia da calha do rio Amazonas. Tese de Doutorado. Programa de Pós-Graduação em Arqueologia do Museu de Arqueologia e Etnologia da Universidade de São Paulo MAE / USP, São Paulo.

Robben, A. C. G. M. 2004. Death and Anthropology: An introduction, in Death, mourning, and burial: a cross-cultural reader. Editado por A. C. G. M. Robben, pp 1-16. Oxford, United Kingdom: Blackwell Publishing.

Roksandic, M. 2002. Position of Skeletal Remains as a Key to Understanding Mortuary Behavior, in Advances in Forensic Taphonomy: Method, Theory and Archaeological Perspectives. Editado por W. D. Haglund e M. H. Sorg, pp. 99-117. CRC Press, Boca Raton.

Rostain, S. 2011. La mort amérindienne en
Amazonie, in Cabiers d'Histoire de l'Amerique Latine 5: 221-254.

Schaan, D. P. 2003. Investigando gênero e organização social no espaço ritual e funerário Marajoara, in XII Congresso da Sociedade de Arqueologia Brasileira, pp. 21-25. São Paulo.

2010. Programa de identificação e salvamento do patrimônio arqueológico BR-163 (Guarantã do Norte/Entroncamento BR-230) e BR-230 (Miritituba/Rurópolis). Relatório semestral de Janeiro a Junho 2010. Belém: Universidade Federal do Pará. Inédito.

Schaefer, M.; S. Black; L. Scheuer. 2009. Juvenile Osteology: A Laboratory and Field Manual. Amsterdam: Elsevier

Shipman, P.; G. Foster; M. Schoeninger. 1984. Burnt bones and teeth: an experimental study of color, morphology, crystal structure and shrinkage, in Journal of $A r$ chaeological Science 11(4): 307-325.

Souza, A. M.a de. 1997. Dicionário de Arqueologia. Rio de Janeiro: ADESA.

Stenborg, P.; D. P. Schaan; M. A. Lima. 2012. Uso da terra e padrão de assentamento pré-colombiano na região de Santarém, Baixo Amazonas, in Amazônica - Revista de Antropologia 4(1): 222-250.

Tylor, E. B. 1920[1871]. Primitive culture: researches into the development of mythology, philosophy, religion, language, art and custom. Londres: J. Murray.

Ubelaker, D. H. 2008. Enterramientos humanos. Excavación, análisis, interpretación. Sociedad de Ciencias Aranzadi.

White, T \& P. A. Folkens. 2005. The buman bone manual. London: Elsevier, Academic Press. 